\title{
Isolation and evaluation of anticancer efficacy of stigmasterol in a mouse model of DMBA-induced skin carcinoma
}

This article was published in the following Dove Press journal:

Drug Design, Development and Therapy

28 May 2015

Number of times this article has been viewed

\author{
Huma Ali' \\ Savita Dixit ${ }^{\prime}$ \\ Daoud Ali ${ }^{2}$ \\ Saeed M Alqahtani ${ }^{3}$ \\ Saad Alkahtani ${ }^{2}$ \\ Saud Alarifi ${ }^{2}$ \\ 'Department of Chemistry, Maulana \\ Azad National Institute of Technology, \\ Bhopal, India; ${ }^{2}$ Department of \\ Zoology, College of Science, King \\ Saud University, Riyadh, Saudi Arabia; \\ ${ }^{3}$ King Abdulaziz City for Science and \\ Technology, Riyadh, Saudi Arabia
}

Correspondence: Huma Ali Department of Chemistry, Maulana Azad National Institute of Technology, Bhopal 462003, India

Email humali.manit@yahoo.com
Abstract: Stigmasterol (99.9\% pure) was isolated from Azadirachta indica and its chemopreventive effect on 7,12-dimethylbenz[a] anthracene (DMBA)-induced skin cancer was investigated in Swiss albino mice. Skin tumors were induced by topical application of DMBA and promoted by croton oil. To assess the chemopreventive potential of stigmasterol, it was orally administered at a concentration of $200 \mathrm{mg} / \mathrm{kg}$ and $400 \mathrm{mg} / \mathrm{kg}$ three times weekly for 16 weeks. Reduction in tumor size and cumulative number of papillomas were seen as a result of treatment with stigmasterol. The average latency period was significantly increased as compared with the carcinogen-treated control. Stigmasterol induced a significant decrease in the activity of serum enzymes, such as aspartate aminotransferase, alanine aminotransferase, alkaline phosphatase, and bilirubin as compared with the control. Stigmasterol significantly increased glutathione, superoxide dismutase, and catalase as compared with the control. Elevated levels of lipid peroxide and DNA damage in the control group were significantly inhibited by administration of stigmasterol. From the present study, it can be inferred that stigmasterol has chemopreventive activity in an experimental model of cancer. This chemopreventive activity may be linked to the oxidative stress of stigmasterol. The antigenotoxic properties of stigmasterol are also likely to contribute to its chemopreventive action.

Keywords: stigmasterol, papilloma, oxidative stress, skin carcinogenesis, chemoprevention, DNA damage

\section{Introduction}

A large number of plant species used in folk medicine have been used since the earliest days of humanity and have considerable importance in international trade. ${ }^{1}$ Azadirachta indica belongs to the Meliaceae family and has been extensively used in Ayurveda, Unani, and homeopathic medicine. More than 135 compounds have been isolated from different parts of $A$. indica. ${ }^{2}$ Plants produce different types of active compounds, including those that can cause DNA damage. ${ }^{3}$ In contrast, some plant metabolites have been shown to reduce the incidence of DNA damage. ${ }^{4}$ Therefore, isolation and characterization of plant products are important for the definition of strategies to reduce the risk of cancer in humans. In this respect, evaluation of the genotoxicity and antigenotoxicity of these plant products is extremely important. ${ }^{5}$

Phytosterols are triterpenes closely resembling cholesterol in both structure and function. They are insoluble in water, but soluble in organic solvents. Stigmasterol, also known as stigmasterin or wulzen anti-stiffness factor, is one of a group of plant sterols present in $A$. indica. The bark of $A$. indica contains tannins, which are phenolic compounds reported to have anti-inflammatory activity. ${ }^{6}$ Toxicology studies of $A$. indica leaf extract 
administered at a dose of $0.6-2.0 \mathrm{~g} / \mathrm{kg}$ bodyweight did not have any lethal effects in terms of hematology, enzyme levels, or histopathological parameters in animals, whereas the leaf extract at $200 \mathrm{~g} / \mathrm{kg}$ caused weight loss accompanied by weakness, anorexia, and histopathological defects. ${ }^{7}$ Stigmasterol is used in a number of chemical processes designed to yield synthetic and semisynthetic compounds in the pharmaceutical industry. ${ }^{8}$ Kaur et $\mathrm{al}^{6}$ reported that stigmasterol has various pharmacological properties, including antiosteoarthritic, hypoglycemic, antimutagenic, antioxidant, and anti-inflammatory activity. The anticarcinogenic activity of stigmasterol has not yet been fully explored. Some investigators have suggested that cancer could be prevented by avoidance of cancer-causing substances and by using chemopreventive agents, ${ }^{9}$ and evaluated the anticancer activity of stigmasterol using parameters such as oxidative stress, DNA damage, histopathological, and liver and kidney function indices.

The present study was designed to study the anticancer efficacy of stigmasterol in Swiss albino mice bearing 7,12dimethylbenz[a]anthracene (DMBA) induced skin cancer.

\section{Materials and methods}

\section{Plant material and extraction}

The leaves of $A$. indica were collected from Maulana Azad Institute National Technology campus, Bhopal, India. The plant material was taxonomically identified by Zia-ULHasan, Department of Botany, Saifia College of Science, Bhopal. The voucher specimen (367/Bot/Saifia/12) was preserved in the above herbarium for future reference. Leaves from $A$. indica were dried in the shade for 7-10 days and pulverized using an electric grinder. The dried sample was extracted in a solvent of methanol and acetone at a ratio of 70:30 using Soxhlet apparatus. The residue was dried under reduced pressure using a rotary vacuum evaporator.

\section{Isolation of stigmasterol}

A column $40 \mathrm{~cm}$ in length and $3 \mathrm{~cm}$ in diameter was plugged with cotton and then packed with silica gel (70 g) up to a height of $23 \mathrm{~cm}$ under reduced pressure. The column was washed with n-hexane to facilitate compact packing. The sample was prepared by adsorbing $3.5 \mathrm{~g}$ of n-hexane soluble extract of $A$. indica onto silica gel (mesh size $60 \mathrm{~mm} \times 120 \mathrm{~mm}$ ), then allowing it to dry, and subsequently applying it on top of the adsorbent layer. The column was then eluted with n-hexane followed by a mixture of n-hexane and dichloromethane, and then a mixture of dichloromethane and methanol. The polarity was gradually increased by adding increasing proportions of dichloromethane and methanol. Thirty fractions were collected, each in $100 \mathrm{~mL}$ beakers.

\section{Characterization of stigmasterol}

Ultraviolet spectral peaks of the compound isolated from $A$. indica showed maximum absorption at $244 \mathrm{~nm}$, indicating the presence of the plant sterol. The Fourier transform infrared data indicated the presence of hydroxyl, alkenes methyl, and methylene groups in the spectrum (Figure 1).

The ${ }^{1} \mathrm{H}$ nuclear magnetic resonance spectrum of the isolated compound exhibited proton signals in $\mu \mathrm{g} / \mathrm{mL}$ at $\delta 5.37$ (1H, H-6), $\delta 5.14$ (1H, H-22), $\delta 5.04$ (1H, H-23), $\delta 2.29$ (1H, $\mathrm{H}-3), \delta 1.09\left(3 \mathrm{H}, \mathrm{CH}_{3}-10\right), \delta 0.95\left(3 \mathrm{H}, \mathrm{CH}_{3}-20\right), \delta 0.846(3 \mathrm{H}$, $\left.\mathrm{CH}_{3}-27\right) \delta 0.81\left(3 \mathrm{H}, \mathrm{CH}_{3}-26\right)$, and $\delta 0.72\left(3 \mathrm{H}, \mathrm{CH}_{3}-13\right)$.

The negative ion electrospray ionization mass spectrum of the isolated compound showed the loss of alkyl groups if the compound is stigmasterol the fragment resulted by loss of $\mathrm{C}_{4} \mathrm{H}_{2}$, loss of methyl and methylene at $\mathrm{m} / \mathrm{z} 507$. It showed loss of $\mathrm{C}_{3} \mathrm{H}_{2} \mathrm{O}_{2}$, loss of the $\mathrm{CO}_{2}$ fragment at $\mathrm{m} / \mathrm{z} 453$, and loss of $\mathrm{C}_{3} \mathrm{H}_{4}$ which is a resonance stabilized fragment at 435. The fragmentation pattern confirmed the presence of stigmasterol.

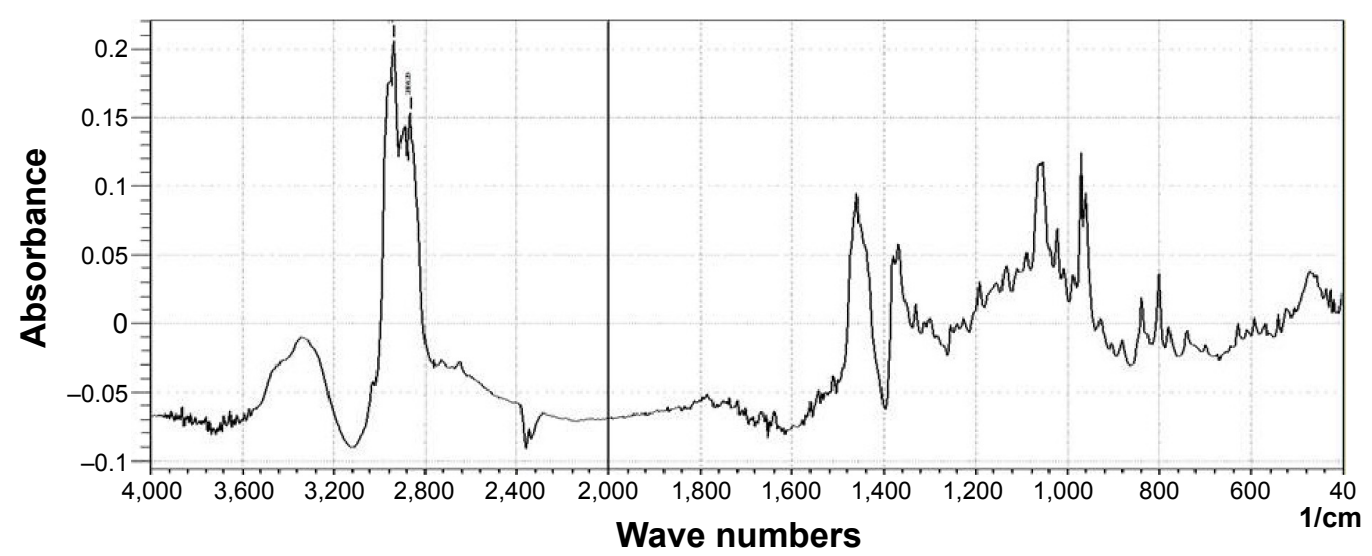

Figure I Characterization of isolated compound (stigmasterol) of Azadirachta indica by Fourier transform infrared spectroscopy. 


\section{Chemicals and animals}

The DMBA and croton oil were purchased from SigmaAldrich (St Louis, MO, USA). Other analytical grade chemicals were purchased from local sources. Swiss albino mice of either sex were selected randomly from the animal house at the Pinnacle Biomedical Research Institute, Bhopal. The animals were housed in polypropylene cages with sterile husk and had access to standard pellets and water ad libitum throughout the experiment. The animals were maintained on a 12 -hour light/dark cycle at $22^{\circ} \mathrm{C} \pm 2{ }^{\circ} \mathrm{C}$ under controlled conditions. All animal experiments were performed with the prior permission of the institutional animal ethics committee at Pinnacle Biomedical Research Institute, Bhopal (1283/C/09/CPCSEA).

\section{Exposure of stigmasterol on DMBA croton oil induced skin carcinoma}

Four groups of Swiss albino mice ( $\mathrm{n}=10$ per group) were used in the study. The animals were dorsally shaved with a hair clipper. Group 1 animals were given Milli-Q water (10 mL/kg body weight), a normal diet, and tap water ad libitum daily. Group 2 animals received a single dose of DMBA $(100 \mu \mathrm{g} / 100 \mu \mathrm{L}$ of acetone $)$ over the shaved area of dorsal skin after which $1 \%$ croton oil was applied to the skin three times a week for 16 weeks. After the single dose of DMBA, the group 3 and group 4 animals were treated with stigmasterol (200 and $400 \mathrm{mg} / \mathrm{kg}$ bodyweight) orally three times a week for 16 weeks, with application of $1 \%$ croton oil onto the skin 1 hour after exposure to stigmasterol. Two weeks after application of DMBA, the mice were monitored weekly for 16 weeks for the presence and size of skin tumors, body weight, and the average latency period. After 16 weeks, the mice were euthanized, and the dorsal skin was removed for histopathology and blood was taken for biochemical analysis.

\section{Oxidative stress biomarkers}

On the final day of the experiment, all the animals were euthanized by cervical dislocation. The dorsal skin was removed immediately and washed in ice-cold saline $(0.9 \% \mathrm{NaCl})$, followed by removal of extraneous material. The skin was then weighed and blotted dry. A 10\% tissue homogenate of skin was prepared in $0.15 \mathrm{M}$ Tris$\mathrm{KCl}$ ( $\mathrm{pH} 7.4$ ), and then centrifuged at 12,000 rpm for 15 minutes. For biochemical estimation, supernatant, were used on the same day. Protein content was measured by the Bradford method, ${ }^{10}$ using bovine serum albumin as the standard.

\section{Lipid peroxidation assay}

Lipid peroxidation (LPO) was estimated by measuring the formation of malondialdehyde. ${ }^{11}$ A mixture of $0.1 \mathrm{~mL}$ tissue lysate and $1.9 \mathrm{~mL}$ of $0.1 \mathrm{M}$ sodium phosphate buffer ( $\mathrm{pH} 7.4$ ) was incubated at $37^{\circ} \mathrm{C}$ for 1 hour. After precipitation with $5 \%$ trichloroacetic acid, the incubation mixture was centrifuged $(2,300 \times g$ for 15 minutes at room temperature) and the supernatant was collected. Next, $1.0 \mathrm{~mL}$ of $1 \%$ thiobarbituric acid was added to the supernatant and placed in boiling water for 15 minutes. After cooling to room temperature, the absorbance of the mixture was taken at $532 \mathrm{~nm}$ and expressed in nmol malondialdehyde per hour/mg protein using a molar extinction coefficient of $1.56 \times 10^{5} / \mathrm{M} / \mathrm{cm}$.

\section{Estimation of glutathione}

The glutathione (GSH) level was quantified using Ellman's reagent. ${ }^{12}$ The assay mixture contained phosphate buffer, 5,5'-dithiobis-(2-nitrobenzoic acid), and tissue lysate. The reaction was monitored at $412 \mathrm{~nm}$ and the amount of GSH was expressed in terms of nmol of $\mathrm{GSH} / \mathrm{mg}$ protein.

\section{Measurement of superoxide dismutase}

The activity of superoxide dismutase (SOD) was estimated using the method described by Kakkar et al. ${ }^{13}$ The assay mixture contained sodium pyrophosphate buffer, nitroblue tetrazolium, phenazine methosulfate, reduced nicotinamide adenine dinucleotide, and tissue lysate. One unit of SOD enzyme activity is defined as the amount of enzyme required to inhibit production of chromogen $(560 \mathrm{~nm})$ by $50 \%$ in 1 minute under assay conditions, and is expressed as specific activity in units $/ \mathrm{min} / \mathrm{mg}$ protein.

\section{Measurement of catalase activity}

Catalase activity was measured by following its ability to split hydrogen peroxide $\left(\mathrm{H}_{2} \mathrm{O}_{2}\right)$ within 1 minute of incubation time. The reaction was then stopped by adding dichromate/ acetic acid reagent, and the remaining $\mathrm{H}_{2} \mathrm{O}_{2}$ was determined by measuring at $570 \mathrm{~nm}$ the chromic acetate formed by reduction of dichromate/acetic acid in the presence of $\mathrm{H}_{2} \mathrm{O}_{2}$, as described earlier. ${ }^{14}$ Catalase activity was expressed as $\mu$ mole $\mathrm{H}_{2} \mathrm{O}_{2}$ decomposed $/ \mathrm{min} / \mathrm{mg}$ protein.

\section{Determination of serum enzymes in stigmasterol-treated mice}

Blood was obtained from all animals by puncturing the retroorbital plexus. The blood samples were allowed to clot for 45 minutes at room temperature. The serum was separated by centrifugation at $2,500 \mathrm{rpm}$ and $30^{\circ} \mathrm{C}$ for 15 minutes and 
utilized for determination of various biochemical parameters. Aspartate aminotransferase, alanine aminotransferase, alkaline phosphatase, and bilirubin levels were estimated using the Span Diagnostics kit.

\section{Histopathology}

After treatment, the mice were sedated and euthanized by decapitation. Fresh portions of skin were rapidly dissected from each mouse, fixed in neutral buffered formalin (10\%), and dehydrated with grades of ethanol $(70 \%, 80 \%, 90 \%$, $95 \%$, and $100 \%$ ). After dehydration, the samples were cleared in two changes of xylene. The samples were then impregnated with two changes of molten paraffin wax, embedded, and blocked out. Paraffin sections (4-5 $\mu \mathrm{m})$ were stained with hematoxylin and eosin. Stained sections from the control and treated mice were observed and photographed using an optical microscope (model BX51 with a digital camera, Olympus, Tokyo, Japan) for alterations in architecture and for the presence of degeneration and necrosis.

\section{Determination of DNA strand breakage}

Alkaline single-cell gel electrophoresis was performed as a three-layer procedure with slight modification. ${ }^{15}$ The lymphocytes were separated from blood using Histopaque density gradient centrifugation and the cells were diluted 20-fold for the Comet assay. For the positive control, lymphocytes were treated with $100 \mathrm{MM} \mathrm{H}_{2} \mathrm{O}_{2}$ for 10 minutes at $4{ }^{\circ} \mathrm{C}$. Two slides per animal were prepared, and 25 cells per slide ( 250 cells per group) were scored randomly and analyzed using a Komet5.5 image analysis system (Kinetic Imaging Ltd, Nottingham Business Park, UK) attached to a fluorescent microscope (Leica, Wetzlar, Germany) equipped with appropriate filters. The parameter selected for quantification of DNA damage was percent tail DNA as determined by the software.

\section{Statistical analysis}

The data obtained from the different groups were analyzed by analysis of variance. $P<0.05$ was considered to be statistically significant for all experiments.

\section{Results \\ Chemopreventive effect of stigmasterol}

The results of the current study are presented in Table 1. A slow decrease in body weight was noticed in the different groups of animals. Group 3 and group 4 animals were continuously treated with different doses of stigmasterol and repeated application of croton oil, and showed significant in the cumulative number of papillomas and tumor size (Figure 2C and D; Table 1) as compared with the control group (group 2, Figure 2B). The latency period was found to be $10.10 \pm 5.17$ weeks in the group treated with DMBA and croton oil, and was significantly higher in the stigmasteroltreated mice (Table 1).

\section{Oxidative stress and biochemical enzymes}

The activity of GSH, SOD, and catalase was increased in the skin of stigmasterol-treated mice (groups 3 and 4) when compared with the control mice (group 2, Figure 3). In contrast, LPO level were significantly decreased in stigmasterol-treated mice when compared with control mice (group 2, Figure 3). A significant decrease in blood aspartate aminotransferase, alanine aminotransferase, alkaline phosphatase, and bilirubin levels in group 3 and group 4 mice when compared with group 2 mice (Table 2).

\section{Effect of stigmasterol on skin histopathology}

Generally, the dermal layer is composed of loose connective tissue and dense connective tissue known as the papillary and reticular layers, respectively. We observed no changes in the structure of the skin in group 1 (Figure 4A). In the animals treated with DMBA and croton oil (Figure 4B), these layers started to differentiate into a papillomatous form, with signs of an epidermal layer with an abnormal structure. Dysplastic changes in the squamous layer, stromal damage, hyperkeratosis, acanthosis, and cysts with horns were observed in the control group treated with DMBA and croton oil (Figure 4B). In the animals treated with stigmasterol,

Table I Chemopreventive effect of stigmasterol against skin carcinogenesis induced by DMBA and croton oil in mice

\begin{tabular}{|c|c|c|c|c|c|}
\hline \multirow[t]{2}{*}{ Treatment } & \multicolumn{2}{|c|}{ Body weight (g) } & \multirow[t]{2}{*}{ Papillomas (n) } & \multirow[t]{2}{*}{ Tumor size $(\mathrm{mm})$} & \multirow{2}{*}{$\begin{array}{l}\text { Average latency } \\
\text { period }^{\#}\end{array}$} \\
\hline & Initial & Final & & & \\
\hline Group I (normal) & $38.12 \pm 4.23$ & $37.56 \pm 5.43$ & & & \\
\hline Group 2 (control) & $26.26 \pm 2.16$ & $22.75 \pm 11.24$ & $10.16 \pm 5.03$ & $2.06 \pm 0.37$ & $10.10 \pm 5.17$ \\
\hline Group 3 (treated) & $28.97 \pm 1.65$ & $25.14 \pm 12.34$ & $3.83 \pm 0.53$ & $1.00 \pm 0.37$ & $12.70 \pm 4.23$ \\
\hline Group 4 (treated) & $29.57 \pm 1.55$ & $26.15 \pm 11.97$ & $1.50 \pm 1.07$ & $0.93 \pm 0.24$ & $13.10 \pm 0.76$ \\
\hline
\end{tabular}

Notes: \#Lag between application of the promoting agent and appearance of $50 \%$ of tumors was determined. Average latency period is $\Sigma$ fx/n; $f$ is the number of tumors appearing each week; $x$ is the number of weeks; $n$ is the total number of tumors.

Abbreviation: DMBA, 7,I2-dimethylbenz[a]anthracene. 

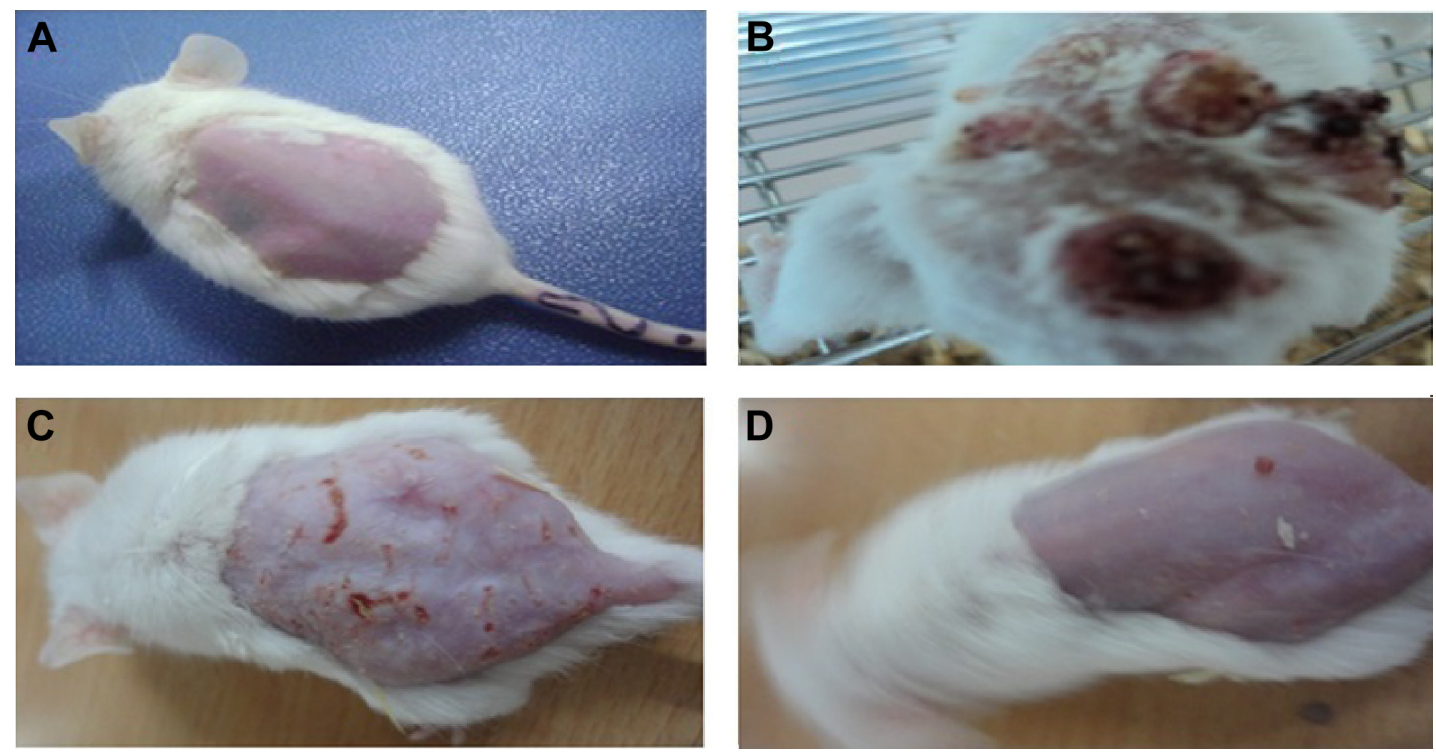

Figure 2 Stigma sterol-induced reduction of tumor in Swiss albino mice.

Notes: (A) Group I (water). (B) Group 2 (water + DMBA + croton oil) with observation on the last day of the experiment. (C) Group 3 (water + stigmasterol 200 mg/kg + DMBA + croton oil). (D) Group 4 (water + stigmasterol $400 \mathrm{mg} / \mathrm{kg}+\mathrm{DMBA}+$ croton oil).

Abbreviation: DMBA, 7,12-dimethylbenz[a]anthracene.

histological observation revealed signs of tumor, hyperkeratosis, and acanthosis, but to a lesser degree when compared with the control group (Figure 4C and D).

\section{DNA damage}

The DNA damage was measured as percent tail DNA and Olive tail moment in the control and treated groups. More DNA damage was observed in the lymphocytes of animals treated with DMBA and croton oil than in the stigmasteroltreated animals (group 2, Figure 5B and E); however, DNA damage was decreased when compared with the control (group 2, Figure 5C-E).

\section{Discussion}

Plant products are natural bioactive compounds that protect against stress and pathogenic attack. It has been reported that long-term use of certain medicinal plants overwhelms carcinogenesis in several human and animal organs. ${ }^{16}$ Thus, it is important to identify natural plant products that could suppress or reverse the process of cancer. ${ }^{1}$ In the present study, we observed several beneficial effects of stigmasterol in induced skin cancer. We used a subthreshold dose of DMBA as a carcinogen followed by regular treatment with croton oil as a promoter to induce skin tumors in experimental mice. With regard to the initiation and promotion

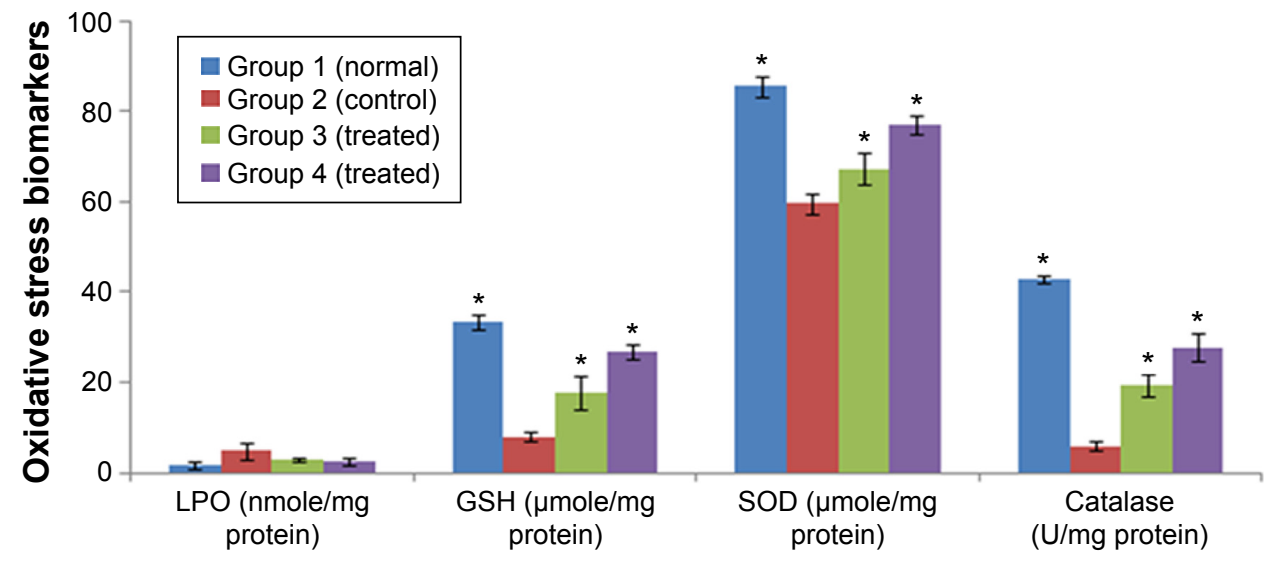

Figure 3 Induction of LPO, GSH, SOD, and catalase levels in Swiss albino mice skin.

Notes: Group I (water). Group 2 (water + DMBA + croton oil) with observation on the last day of the experiment. Group 3 (water + stigmasterol $200 \mathrm{mg} / \mathrm{kg}+\mathrm{DMBA}+$ croton oil). Group 4 (water + stigmasterol $400 \mathrm{mg} / \mathrm{kg}+\mathrm{DMBA}+$ croton oil). Each value represents the mean \pm standard error of duplicate experiments. $* P<0.05$ vs control.

Abbreviations: DMBA, 7,I2-dimethylbenz[a]anthracene; GSH, glutathione; LPO, lipid peroxidation; SOD, superoxide dismutase. 
Table 2 Effect of stigmasterol on serum enzyme levels

\begin{tabular}{llll}
\hline Treatment & AST (IU/L) & ALT (IU/L) & ALP (IU/L) \\
\hline Group I (normal) & $58.33 \pm 1.47^{*}$ & $34.45 \pm 1.75^{*}$ & $30.29 \pm 0.73^{*}$ \\
Group 2 (control) & $162.73 \pm 6.33$ & $149.06 \pm 4.6$ & $231.52 \pm 9.03$ \\
Group 3 (treated) & $111.42 \pm 7.72^{*}$ & $102.00 \pm 7.34 *$ & $1.12 \pm 0.03^{*}$ \\
Group 4 (treated) & $101.37 \pm 6.36^{*}$ & $81.66 \pm 2.40^{*}$ & $2.68 \pm 4.98 *$ \\
\hline
\end{tabular}

Notes: Each value represents the mean \pm standard error of duplicate experiments. $* P<0.05$ vs control.

Abbreviations: AST, aspartate aminotransferase; ALT, alanine aminotransferase; ALP, alkaline phosphatase.

stages, animal studies show that the promotion step takes more time to occur and is reversible initially, so prevention of cancer by inhibition of tumor promotion is expected to be an inventive approach. In the current study, stigmasterol could significantly inhibit formation DMBA-induced papilloma in terms of both incidence of tumors and the mean number of papillomas.

LPO is a free radical chain reaction and is well known to induce two main steps, ie, initiation and promotion of carcinogenesis. LPO level is increased and produced a complex reactive compounds, eg, malondialdehyde. The products of LPO have been reported to be mutagenic and carcinogenic. Roslida et al ${ }^{17}$ used chemopreventive agents to reduce production of free radicals in vivo. In our study, administration of stigmasterol significantly reduced the level of LPO in mice treated with DMBA and croton oil, and as a consequence, decreased the incidence of skin tumors.

GSH has an important role in normal cell metabolism, ie, inhibiting production of reactive oxygen species (ROS) and free radicals. We found that GSH activity was decreased in the control group (treated with DMBA + croton oil) but was increased in stigmasterol-treated mice, indicating its antioxidant activity. Klaunig et al ${ }^{18}$ reported that antioxidants have chemopreventive properties. Antioxidants are considered to be the first line of defense against oxidative stress, which suggests their usefulness in reducing the risk of oxidative damage during carcinogenesis. SOD and catalase are antioxidative enzymes that protect against ROS. ${ }^{19} \mathrm{We}$ observed significant enrichment of GSH and SOD levels and catalase activity in the stigmasterol-treated group when compared
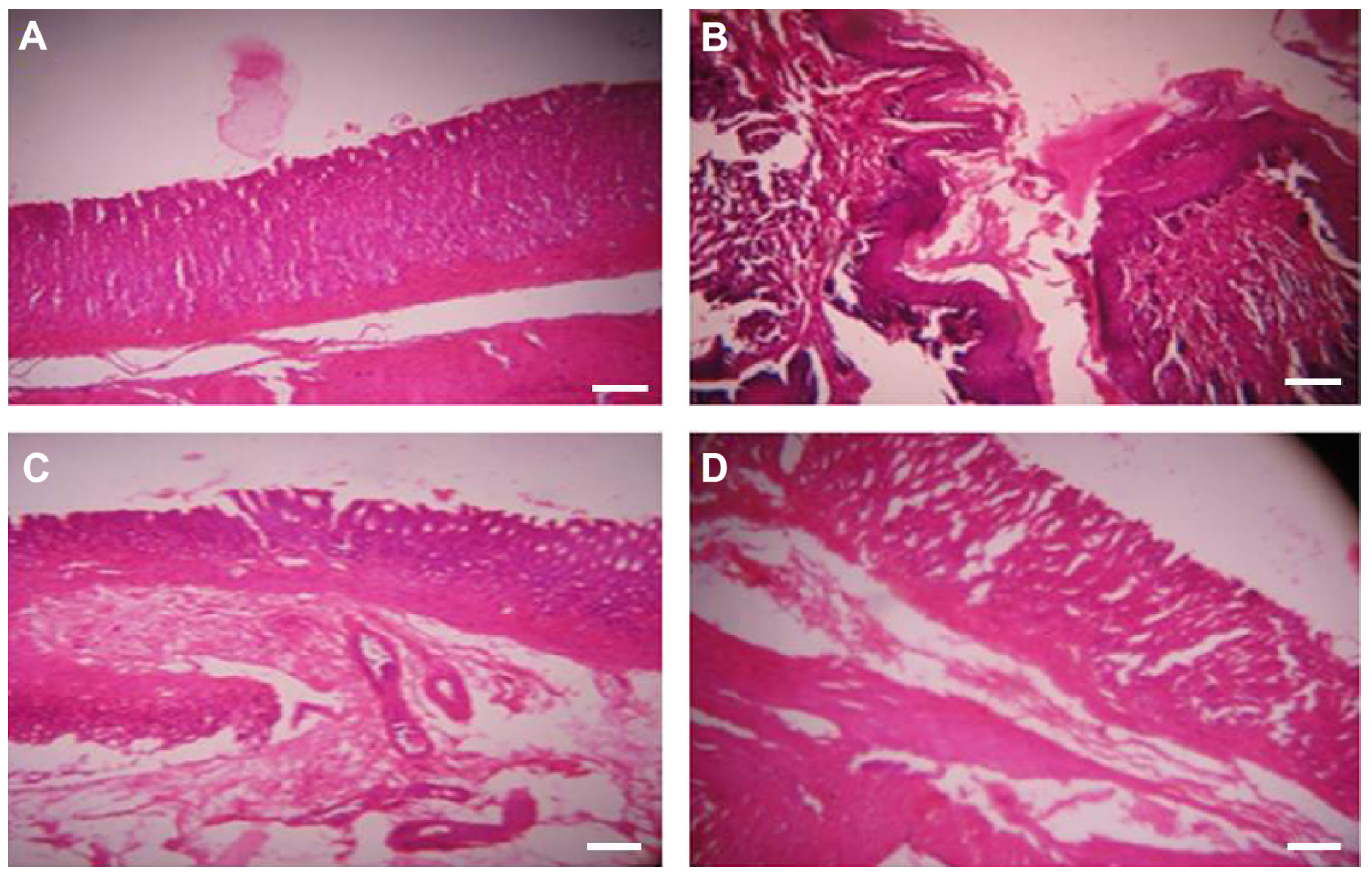

Figure 4 Cross-sections from Swiss albino mice skin stained with hematoxylin-eosin.

Notes: (A) Group I (water). (B) Group 2 (water + DMBA + croton oil) with observation on the last day of the experiment. (C) Group 3 (water + stigmasterol $200 \mathrm{mg} / \mathrm{kg}$ + DMBA + croton oil). (D) Group 4 (water + stigmasterol $400 \mathrm{mg} / \mathrm{kg}+$ DMBA + croton oil). Scale bar $30 \mu \mathrm{m}$.

Abbreviation: DMBA, 7,12-dimethylbenz[a]anthracene. 

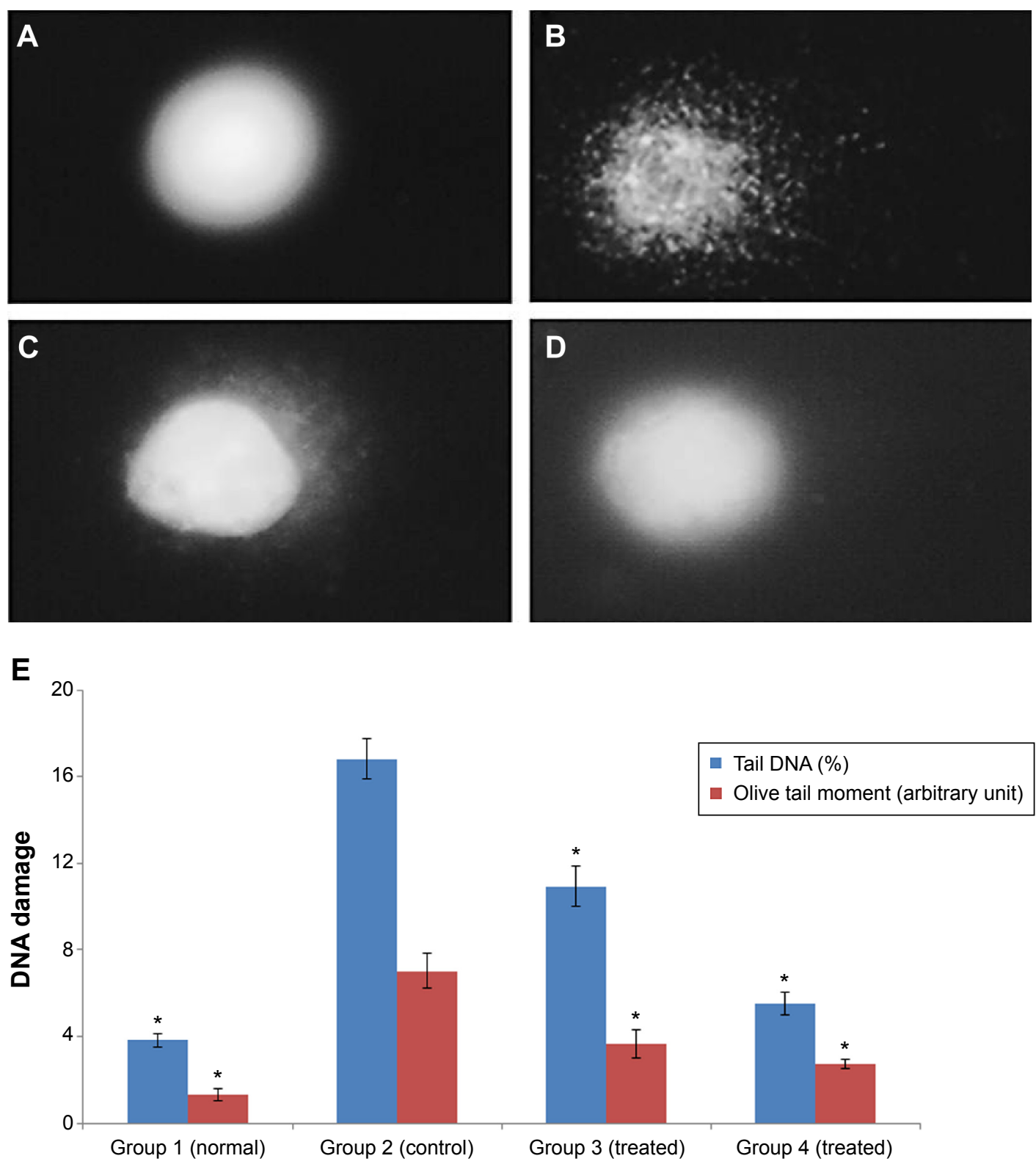

Figure 5 DNA damage in lymphocytes from Swiss albino mice.

Notes: (A) Group I (water). (B) Group 2 (water + DMBA + croton oil). (C) Group 3 (water + stigmasterol $200 \mathrm{mg} / \mathrm{kg}+\mathrm{DMBA}+\mathrm{croton}$ oil). (D) Group 4 (water + stigmasterol $400 \mathrm{mg} / \mathrm{kg}+\mathrm{DMBA}+$ croton oil). (E) DNA damage as percent tail DNA and Olive tail moment. Each value represents the mean \pm standard error of duplicate experiments. $* P<0.05$ vs control.

Abbreviation: DMBA, 7,12-dimethylbenz[a]anthracene.

with the control group. ROS play an important role in the process of apoptosis, and include the superoxide, hydrogen peroxide, and hydroxyl radicals, which damage cell components including DNA, ultimately leading to cell death. ${ }^{20}$

Exposure to DMBA induces LPO and ROS in the affected area of skin, leading to carcinogenesis. ROS cause permeabilization of the outer mitochondrial membrane, which releases soluble proteins from the inner membrane space into the cytosol, and promote caspase activation. ${ }^{21}$ Oxidative stress was observed in the control groups because LPO was high and GSH, SOD, and catalase levels were low. The beneficial effect of stigmasterol is probably due to its ability to stimulate antioxidant enzymes in cells. The increase in enzyme activity down the production of ROS and LPO in the skin, decreased the incidence of papilloma in the areas of treated skin.

Histopathological observation showed that DMBA caused severe skin damage. The histopathology study showed that stigmasterol repaired the degenerated epidermal and dermal layers of skin in the group 2 animals. However, significant histological changes were observed in the hypodermis, 
Table 3

\begin{tabular}{ll}
\hline Bands & Frequencies \\
\hline$v(\mathrm{O}-\mathrm{H})$ & $\left(3,650-3,200 \mathrm{~cm}^{-1}\right)$ stretch \\
$v(\mathrm{C}-\mathrm{H})$ & $\left(2,935 \mathrm{~cm}^{-1}\right)$ stretch of alkene hydrogens \\
$v(\mathrm{C}-\mathrm{H})$ & $\left(2,835 \mathrm{~cm}^{-1}\right)$ stretch of $\mathrm{CH}_{2}$ and $\mathrm{CH}_{3}$ \\
$v(\mathrm{C}=\mathrm{C})$ & $\left(\mathrm{I}, 550 \mathrm{~cm}^{-1}\right)$ stretch \\
Deformation vibration & $\left(1,380 \mathrm{~cm}^{-1}\right) \mathrm{CH}_{3},(\mathrm{I}, 450) \mathrm{CH}_{2}$ \\
Out of plane bending & $(\mathrm{I}, 050-980) \mathrm{CH}_{2},(750-800) \mathrm{CH}=\mathrm{CH}$ \\
\hline
\end{tabular}

where there was degeneration of adipose tissue. Thus, the free hydroxyl group on the aromatic ring is responsible for the antioxidant properties. The Comet assay showed that DMBA induced significant DNA damage in lymphocytes. The protective effect of $A$. indica against DNA damage in lymphocytes might be due to the stigmasterol present in the ethanol leaf extract.

The present results show the anticancer effect of stigmasterol at the higher concentrations tested $(200$ and $400 \mathrm{mg} / \mathrm{kg}$ body weight). Further, we found that stigmasterol had an antigenotoxic effect on DMBA-induced genotoxicity. These results suggest that the anticancer activity of stigmasterol may be due to its antioxidant and antigenotoxic properties.

\section{Acknowledgment}

The authors are grateful to the Deanship of Scientific Research at King Saud University for funding this research (RG-1435-076).

\section{Disclosure}

The authors report no conflicts of interest in this work.

\section{References}

1. Ebong PK, Atangwho IJ, Eyong EU, Egbung GE. The anti-diabetic efficacy of combined extracts from two continental plants: Azadirachta indica (A. juss) (Neem) and Vernonia amygdalina (Del.) (African bitter leaf). Am J Biochem Biotechnol. 2008;4:239-244.

2. Chopra RN, Nayer SL, Chopra IC. Glossary of Indian Medicinal Plants. New Delhi, India: Council of Scientific and Industrial Research; 1956.

3. Ansah C, Khan A, Gooderham NJ. In vitro genotoxicity of the West African antimalarial herbal Cryptolepis sanguinolenta and its major alkaloid cryptolepine. Toxicology. 2005;208:141-147.
4. Vieira PM, Marinho LP, Ferri SC, Chen-Chen L. Protective effects of steroidal alkaloids isolated from Solanum paniculatum L. against mitomycin cytotoxic and genotoxic actions. An Acad Bras Cienc. 2013; 85:553-560.

5. Vieira PM, Santos SC, Chen-Chen L. Assessment of mutagenicity and cytotoxicity of Solanum paniculatum L. extracts using in vivo micronucleus test in mice. Braz J Biol. 2010;70:601-606.

6. Kaur N, Chaudhary J, Jain A, Kishore L. Stigma sterol: a comprehensive review. Int J Pharm Sci Res. 2011;2:2259-2265.

7. Ghimeray AK, Jin C, Ghimire BK, Cho DH. Antioxidant activity and quantitative estimation of azadirachtin and nimbin in Azadirachta indica (A. Juss) grown in foothills of Nepal. Afr J Biotechnol. 2009;8: 3084-3091.

8. Fernandes P, Cabral JM. Phytosterols: applications and recovery methods. Bioresour Technol. 2007;98:2335-2350.

9. Sharma P, Parmar J, Verma P, Sharma P, Goyal PK. Anti-tumor activity of Phyllanthus niruri (a medicinal plant) on chemical-induced skin carcinogenesis in mice. Asian Pac J Cancer Prev. 2009;10:1089-1094.

10. Bradford MM. A rapid and sensitive method for the quantitation of microgram quantities of protein utilizing the principle of protein-dye binding. Anal Biochem. 1976;72:248-254.

11. Ohkawa H, Ohishi N, Yagi K. Assay for lipid peroxides in animal tissues by thiobarbituric acid reaction. Anal Biochem. 1979;95:351-358.

12. Ellman G. Tissue sulfhydryl groups. Arch Biochem Biophys. 1959; 82:70-77.

13. Kakkar PS, Das B, Viswanathan PN. A modified spectrophotometric assay of superoxide dismutase. Indian J Biochem Biophys. 1984;21: 130-132.

14. Sinha AK. Colorimetric assay of catalase. Anal Biochem. 1972;47: 389-394.

15. Ali D, Ray RS, Hans RK. UVA-induced cyototoxicity and DNA damaging potential of benz (e) acephenanthrylene. Toxicol Lett. 2010;199:193-200.

16. Mouli KC, Vijaya T, Rao SD. Phyto-resources as potential therapeutic agents for cancer treatment and prevention. Journal of Global Pharma Technology. 2009;1:4-18

17. Roslida AH, Fezah O, Yeong LT. Suppression of DMBA/croton oilinduced mouse skin tumor promotion by Ardisia crispa root hexane extract. Asian Pac J Cancer Prev. 2011;12:665-669.

18. Klaunig JE, Kamendulis LM, Hocevar BA. Oxidative stress and oxidative damage in carcinogenesis. Toxicol Pathol. 2010;38:96-109.

19. Ekin S, Ozdemir H, Demir H, et al. Plantago major protective effects on antioxidant status after administration of 7,12-dimethylbenz(a) anthracene in rats. Asian Pac J Cancer Prev. 2011;12:531-535.

20. Parmar J, Sharma P, Verma P, Sharma P, Goyal PK. Anti-tumor and anti-oxidative activity of Rosmarinus officinalis in 7, 12 dimethyl benz(a) anthracene induced skin carcinogenesis in mice. Am J Biomed Sci. 2011;3:199-209.

21. Blessy D, Suresh K, Manoharan S, Vijayaanand MA, Sugunadevi G. Evaluation of chemopreventive potential of Zingiber officinale roscoe ethanolic root extract on 7, 12-dimethyl benz[a] anthracene induced oral carcinogenesis. Res J Agric Biol Sci. 2009;5:775-781.
Drug Design, Development and Therapy

\section{Publish your work in this journal}

Drug Design, Development and Therapy is an international, peerreviewed open-access journal that spans the spectrum of drug design and development through to clinical applications. Clinical outcomes, patient safety, and programs for the development and effective, safe, and sustained use of medicines are a feature of the journal, which

\section{Dovepress}

has also been accepted for indexing on PubMed Central. The manuscript management system is completely online and includes a very quick and fair peer-review system, which is all easy to use. Visit http://www.dovepress.com/testimonials.php to read real quotes from published authors. 